\title{
Research on the Strategy to Actively Promote Real Estate Tax Reform in China
}

\author{
Zhenyi Xu \\ Law School of Washington University in St. Louis, St. Louis 63130, USA
}

\begin{abstract}
Since the abolition of the welfare housing distribution policy and the implementation of the monetary reform of the housing system in 1998, there has even been a bubble phenomenon despite the rapid development of the Chinese real estate market. However, considering that the reform of real estate tax will affect the whole system, and there are still various disputes about real estate tax in society, the Chinese government is very slow in real estate tax reform. Given this, under the background that the State Council has been authorized by the Standing Committee of the National People's Congress to pilot real estate tax reform, it is still necessary to explore the legitimacy of China's real estate tax reform promotion. In general, under the background of solidly promoting common prosperity, resolutely implementing the policy of "housing to live without speculation," and promoting the stable and healthy development of the real estate market, coupled with the fact that the real estate market has already seen a severe bubble phenomenon. China's active promotion of real estate tax reform has a solid theoretical and practical basis and has urgency and feasibility.
\end{abstract}

Keywords: Real Estate, Real Estate Regulation, Real Estate Tax, Real Estate Tax Reform

Correspondence to: Zhenyi Xu, Law School of Washington University in St. Louis, St. Louis 63130, USA

Received: July 29, 2021; Accepted: November 12, 2021; Published: November 23, 2021.

Citation: Xu Z. Research on the Strategy to Actively Promote Real Estate Tax Reform in China. Journal of Smart Cities, 2021, 6(1): 1-8. https://doi.org/10.26789/JSC.2021.01.001

Copyright: Research on the Strategy to Actively Promote Real Estate Tax Reform in China. (C) 2021 Zhenyi Xu. This is an Open Access article published by Urban Development Scientific Publishing Company. It is distributed under the terms of the Creative Commons Attribution-Noncommercial 4.0 International License, permitting all non-commercial use, distribution, and reproduction in any medium, provided the original work is properly cited and acknowledged.

\section{Introduction}

Since the State Council promulgated the "Decision on the Implementation of a Tax-sharing Fiscal Management System" on December 15, 1993, to continuously promote the reform of the tax-sharing fiscal system in China. Under the background that the Chinese government began to implement the monetary reform of the housing system in 1998, the real estate tax has always been a critical topic in the fiscal and taxation system reform. It has attracted attention from all walks of life. However, real estate tax reform affects the whole system. In the process of China's fiscal and taxation system reform, ${ }^{[1]}$ there has never been a tax reform as difficult as the real estate tax reform. This is not only because of the decades-long debates around the reform of real estate tax in all sectors of society but also because the Chinese government has been in a state of inadequate actions on the reform of real estate tax.

As early as October 14, 2003, the Third Plenary Session of the 16th Central Committee of the Communist Party of China clearly stated that "a unified and standardized property tax should be imposed on real estate when conditions are met." Although this is considered the clarion call for China's real estate tax reform, the reform has not been advanced in time. Until the world financial crisis in 2008, the "Outline of the Twelfth Five-Year Plan for National Economic and Social Development" reviewed and approved by the Fourth Session of the Eleventh National People's Congress on March 14, 2011, once again proposed "Research and Promotion of Real Estate Tax Reform.” According to this outline, on January 28, 2011, the Shanghai and Chongqing municipal governments began to implement pilot individual housing property tax reforms. After the real estate tax reform pilots in Shanghai and Chongqing, the decision-making and deployment of the real estate tax reform have been further strengthened. On November 12, 2013, the "Decision of the Central Committee of the Communist Party of China on Several Major Issues of Comprehensively Deepening Reform" passed at the Third Plenary Session of the 18th Central Committee of the Communist Party of China further required "speed up legislation on real estate tax and advance reform on time." On March 16, 2016, the "Outline of the Thirteenth Five-Year Plan for National Economic and Social Development" approved by the Fourth Session of the Twelfth National People's Congress clearly stated that "improving the local tax system and advancing real estate tax legislation." On March 11, 2021, the "Fourteenth Five-Year Plan for National Economic and Social Development and the Outline of Long-Term Goals for 
2035" passed by the Fourth Session of the 13th National People's Congress further proposes to "promote real estate tax legislation, improve the local tax system, and gradually expand the power of local tax administration." On October 31, 2019, the "Decision of the Central Committee of the Communist Party of China on Several Major Issues Concerning Upholding and Improving the Socialist System with Chinese Characteristics to Promote the Modernization of the National Governance System and Governance Capacity" adopted by the Fourth Plenary Session of the 19th Central Committee of the Communist Party of China clearly stated: "Improve the redistribution adjustment mechanism with taxation, social security, transfer payment as the main means, strengthen taxation adjustment, improve the direct tax system and gradually increase its proportion." On October 23, 2021, in order to actively and steadily advance the legislation and reform of real estate tax, guide reasonable housing consumption and economic and intensive use of land resources, and promote the steady and healthy development of the real estate market, The thirty-first meeting of the Standing Committee of the Thirteenth National People's Congress passed a decision authorizing the State Council to carry out pilot projects for real estate tax reform in certain areas.

Although the "Decision on Authorizing the State Council to Carry out Real Estate Tax Reform Pilot Work in Certain Regions" marks the acceleration of the process of China's real estate tax reform, the pilot work and legislative work on the real estate tax reform have been put on the agenda. However, there are still various controversies surrounding the reform of real estate tax. In particular, society still has significant doubts about the legitimacy of the state's real estate tax reform promotion. For example, some scholars believe that the ownership of land in China belongs to the state. When citizens purchase commercial houses, they only have the right to use the land but do not enjoy ownership. There is no legal basis for the state to impose a real estate tax on commercial houses with only 70 years of land use rights. Some scholars believe that in the process of auctioning land, building houses, and citizens buying commercial houses, the developers and commercial house owners have already paid two things such as land transfer fees, value-added land tax, business tax, personal income tax, deed tax, stamp tax. There are more than ten kinds of taxes and fees. If the real estate tax is levied on the owners of commercial houses, it will be double taxation. The reform will not only increase the burden on citizens but also undermine fairness. Some scholars believe that advancing the real estate tax reform not only fails to fundamentally strengthen the regulation of the real estate market and curb the real estate bubble, but it may be detrimental to the steady and healthy development of the real estate market. ${ }^{[2-5]}$ Some scholars believe that China does not yet have the conditions to promote real estate tax reform. If the real estate tax is levied blindly, it will have a series of adverse effects, such as triggering violent fluctuations in the real estate market, leading to a substantial reduction in com- mercial housing owners' wealth and a substantial increase in the economic burden of renters. Some scholars believe that China's national conditions are different from Western countries, and China's real estate tax reform still faces a series of difficult-to-operate or difficult-to-solve problems. For instance, the real estate tax collection object, tax rate setting, tax basis, exemption standard, valuation of commercial housing, unpredictable tax effect, collection procedures. The above views have certain truths. However, under the background of solidly promoting common prosperity, resolutely implementing the "housing to live without speculation" policy, and promoting the stable and healthy development of the real estate market, coupled with the fact that the real estate market has already experienced a severe bubble phenomenon, China's active promotion of real estate tax reform is not only imminent but also has a solid theoretical and practical basis. In order to smoothly advance the real estate tax reform, it is necessary to thoroughly understand in theory the legitimacy of the real estate tax reform to respond to the various doubts of the opponents effectively. This article intends to discuss the legitimacy of China's active promotion of real estate tax reform from the following four aspects.

\section{Theoretical basis for China's active promotion of real estate tax reform}

First of all, China's active promotion of real estate tax reform conforms to the benefit theory in the modern tax system. In the theoretical study of China's real estate tax, a representative point of view is that when the land is owned by the state or collective, the real estate owner does not have land ownership but only enjoys 70 years of land use rights. Therefore, government departments do not have a sufficient basis for levying real estate taxes on real estate with only land-use rights. Although many Western countries that levy real estate taxes implement private land ownership, modern real estate taxes are not necessarily related to land ownership. According to the public ownership of land in China, it is undeniable that real estate owners cannot enjoy land ownership. However, according to China's civil law, the land use rights of real estate owners are protected by national laws, and real estate owners have the right to transfer, lease, mortgage, and a series of rights such as inheritance. According to modern civil law theory, land use rights are property rights like land ownership. Whether it is land use rights or land ownership, real estate owners benefit from purchasing houses because they enjoy a series of property rights protected by national laws, and real estate owners occupy specific land resources because of the use of the real estate. According to the benefit theory in the modern taxation system, the real estate tax is levied on buildings and buildings. It is essentially taxation of various property rights based on the building and has no substantial connection with the ownership of the land. In other words, as long as the real estate owner obtains income from the house he holds, the state has the right to impose a specific 
tax on the real estate owner, regardless of whether this kind of house is built based on land use rights or based on land ownership. In fact, from the perspective of foreign real estate tax systems, although many countries that implement real estate taxes implement private land ownership, many countries and regions that implement real estate taxes (such as Singapore and Israel) implement public land ownership. Because of this, China's public land ownership system cannot become an obstacle to collecting real estate taxes. It is impossible to deny the legitimacy of the collection of real estate taxes because Chinese houses only have land-use rights.

Second, China's active promotion of real estate tax reform conforms to the theory of public finances. Modern public finance theory believes that when land and its real estate have property attributes, the theory of property taxation is undoubtedly applicable to real estate taxation. Take the fiscal revenue theory and social function theory in the theory of public finance as examples. From the perspective of fiscal revenue theory, real estate and land have the characteristics of a comprehensive tax base, immovability, and convenient collection and management. These characteristics determine that real estate tax can naturally be used as the primary tax category of local taxes, bringing local governments sustainable and stable tax sources. From a global perspective, the real estate tax is the essential local tax. Real estate taxes levied by local governments are usually used for social public service expenditures. In this case, the degree of real estate appreciation and the collection of real estate taxes can directly affect the level of local fiscal revenue and indirectly affect the level of public services provided by local governments to residents. According to the principle of fairness corresponding to income and expenditure, since the residents in the area enjoy the high-quality public services provided by the local government, they have the responsibility to bear the corresponding real estate tax. From the perspective of social function theory, property tax is a state tax on the stock of social wealth. This determines that the property tax is essentially the regulation of people's wealth and income, and it is a crucial tax that promotes the equitable development of society. Real estate and land taxation are because real estate and land are taxable properties and because taxes can regulate social wealth, curb speculation, combat unearned gains, narrow the gap between the rich and the poor, and promote social equity.

Finally, China's promotion of real estate tax reform conforms to the theory of macro-control. From a global perspective, many countries levy real estate taxes mainly because of the tax types set to curb the real estate bubble when the real estate market is overheating. As far as the role of real estate regulation is concerned, the state's collection of real estate taxes can curb excessive real estate prices through two aspects. On the one hand, real estate taxes can directly affect the supply and demand in the real estate market, thereby affecting housing prices. On the other hand, real estate taxes can influence the behavior and decision-making of local gov- ernments, thereby indirectly regulating housing prices in the real estate market. The collection of real estate tax can play a macro-control role in restraining the real estate bubble mainly because the collection of real estate tax conforms to two macro-control theories. One is the premium recovery theory. Although the increase in population and the optimization of land can increase land value, fundamentally speaking, the increase in land value is mainly due to the government providing society with higher-quality public facilities. This means that the increase in land value is mainly attributed to the government, and there is no important connection with real estate owners and users. Under this circumstance, real estate holders and users do not have sufficient reasons to obtain the increased land value. As real estate prices rise or real estate appreciation is essentially an increase in land value, government departments have the right to collect real estate taxes to recover this part of the land appreciation income originally attributable to the government. The other is the failure theory of the real estate market. According to the basic principles of economics, although the market has the function of free adjustment, due to the asymmetry of information acquisition, spillover effects, imperfect market competition, and other reasons, the market often fails, and it is difficult to achieve the most optimal allocation of resources. Due to land monopoly, information asymmetry in real estate transactions, and externalities of real estate prices, the real estate market will also have failure problems. Since the real estate market involves more than 60 industries, the failure of the real estate market will often cause fluctuations in economic growth, making it difficult to achieve the optimal allocation of resources, leading to market imbalances. In this case, government departments can effectively regulate the real estate market by levying real estate taxes, reversing the situation of market failure, and ensuring that the real estate market returns to equilibrium.

\section{The realistic basis for China to ac- tively promote the reform of real es- tate tax}

First of all, China's active promotion of real estate tax reform is necessary to curb the real estate bubble. In order to promote the housing industry to become a new economic growth point, the State Council promulgated the "Notice on Further Deepening the Reform of the Urban Housing System and Accelerating Housing Construction" in 1998, announcing that the physical distribution of housing will be stopped starting from the second half of the year. The monetization of housing distribution will be gradually implemented. After the cancellation of welfare housing allocation and the implementation of the monetization of the housing system, housing construction has developed rapidly, the real estate market has developed rapidly, and residents' demand for housing purchases have been ultimately released, resulting in a real estate bubble phenomenon of overheated real estate market and ex- 
cessively high housing prices. From a global perspective, the experience of foreign real estate tax system reforms shows that the real estate tax system reform can help realize the real estate market regulation, curb real estate speculation, and stabilize the development of the real estate market. In many countries that implement real estate taxes, the real estate market bubble has been effectively controlled. Real estate prices are reflected in the changes in housing prices before and after the real estate tax system reform. Real estate tax reforms, which usually help reduce the burden of real estate taxation, will curb the rise in housing prices, while real estate tax policies aimed at combating real estate speculation and increasing the cost of real estate holdings will cause housing prices to fall. China's real estate market has already experienced a severe bubble phenomenon to prevent the economic crisis or financial crisis caused by the real estate bubble burst. Given this, China urgently needs to use real estate tax reform to curb the overheating of the real estate market and promote stable, healthy, and sustainable development.

Secondly, China's active promotion of real estate tax reform is necessary to implement the policy of "no speculation on housing and housing." Since the abolition of welfare housing allocation and the monetization of the housing system in 1998, under the influence of multiple factors such as the acceleration of reform and opening up, demographic dividends, accelerated urbanization, and land finance, China's real estate market has ushered in unprecedented opportunities. While China's real estate market has made remarkable achievements, it has also been overheated and bubbled. In order to maintain the healthy and sustainable development of the real estate market, prevent the economic or financial risks caused by the real estate bubble, and curb excessively high real estate prices, The Central Economic Work Conference held at the end of 2016 and 2019 successively proposed the real estate control policy that "housing is not for speculation." The real estate tax has become a sharp weapon for implementing the regulation policy of "housing to live without speculation" because it can effectively curb the growth and spread of the real estate bubble. This is because, under the condition that real estate tax can effectively suppress the real estate bubble, real estate tax reform can change the real estate investment income and housing consumption choices of both real estate supply and demand, increase real estate holding costs, effectively reduce speculation in the real estate market, and realize the optimal allocation of real estate resources. Furthermore, when the real estate market is overheated or speculative behavior is severe, speculators have a decisive influence on real estate prices because they belong to the transaction subjects in the market. In the case of imposing a real estate tax on real estate ownership, real estate tax reform can increase the cost of real estate holdings for speculators. In anticipation of the imposition of the real estate tax, if real estate speculators continue to hold real estate, they will inevitably bear the tax burden of the real estate tax, which will increase the difficulty of speculation and profit, and prompt speculators to sell real estate before the tax is imposed. This leads to an increase in the supply of real estate in the short term, thereby reducing the price of real estate. The decision to impose a real estate tax when speculation in the real estate market is prevailing is a measure of welfare for buyers who truly live for housing. This is because when the real estate price is overestimated, by deferring the payment of part of the real estate price, they have the opportunity to purchase real estate only by paying a lower actual price.

Finally, China's active promotion of real estate tax reform is the need to deepen the fiscal and taxation system reform. Except for a minimal number of countries, most countries have separate central and local governments. Under the principle of first-level government and first-level finance, there is a problem of the fiscal system between the central government and the local government, that is, how to determine the responsibilities and budgetary revenue and expenditure authority between the central government and local governments, as well as local governments at all levels. As far as the world is concerned, developed countries with market economies generally implement a tax-sharing fiscal system that handles the financial relationship between the central and local governments by dividing financial and tax powers. Since 1994, although the Chinese government has continuously deepened the reform of the fiscal and taxation system, there are still severe problems in the current fiscal and taxation system. For example, the proportion of tax revenue in the distribution of social wealth has gradually increased, and the actual tax burden of enterprises and residents has become too large, creating a situation of "the country is rich, and the people are poor." Another example is the unreasonable tax structure, low turnover tax, low-income tax, and stock tax, which are not conducive to adjusting income distribution and the gap between the rich and the poor. As far as the real estate market is concerned, China's tax system also has apparent problems. One is the mixture of taxes and fees related to real estate. From land development to real estate transactions, and from real estate transactions to real estate preservation, there are corresponding tax and fee regulations, forming an overly complicated real estate tax and fee system. In the process of real estate development and transaction, land rent and fees are far greater than taxes. This phenomenon has increased the cost of real estate development, distorted the operating behavior of market entities, increased the actual burden of real estate consumers, affected the normal development of the real estate market, and led to the failure of the macrocontrol function of taxation to be effectively performed. The second is the unreasonable structure of the tax system, which emphasizes the circulation link and neglects the holding link. Although China's real estate tax system involves multiple links of development, transaction, and preservation, the total tax and fee of land acquisition for real estate development account for more than $70 \%$ of the housing price, leading to land finance. This can be an important reason why China's real estate regulation is difficult to curb housing prices. Third, due 
to the unreasonable design of the tax system, the residents' self-use stock houses are not within the scope of taxation, and there is no real estate tax in the real estate tax system in China. This unreasonable tax and fee design not only deviates from the principle of fairness in taxation but also stimulates speculation in real estate and widens the gap between the rich and the poor. In order to give full play to the regulatory function of the real estate tax, China urgently needs to promote real estate tax reform, reduce taxes on real estate circulation, increase taxes on real estate ownership, make real estate tax the main tax for local governments, and reduce local governments' dependence on land finance.

\section{The urgency of China's active pro- motion of real estate tax reform}

First, China's active promotion of real estate tax reform is essential to achieve common prosperity. Since the reform and opening up, with the establishment of the socialist market economic system and the in-depth implementation of reform and opening-up policies, China has undergone earth-shaking changes in politics, economy, culture, and society. China has made remarkable achievements that have attracted worldwide attention. Its economic aggregate has leaped to second place in the world. It has established an independent and relatively complete national economic system, its economic strength and overall national strength have been significantly enhanced, and a complete modern industrial system has been established. With the tremendous economic development, China has not only solved the problem of food and clothing but has also reached a moderately prosperous level in general. Although China's economy has made brilliant achievements, with the acceleration of the transformation of social organization, employment structure, and social structure, China is also facing a series of deep-seated problems, such as shortage of resources and energy, severe ecological pollution, unbalanced urban and rural development, and regional development. Unbalanced, unbalanced economic and social development, the large gap between rich and poor. It is against this background that since the 18th National Congress of the Communist Party of China, the Central Committee of the Communist Party of China has grasped the new changes in the development stage and put the gradual realization of common prosperity for all people in a more important position. The report of the 19th National Congress of the Communist Party of China put forward achieving common prosperity for all people. The tenth meeting of the Central Finance and Economics Committee specifically studied the issue of solidly promoting common prosperity. It can be said that common prosperity is the essential requirement and goal of socialism, an essential feature of China's modernization, the fundamental principle of socialism with Chinese characteristics, and the common expectation of the people. In order to achieve the goal of common prosperity, China must adjust the pattern of the national income distribution, deepen the reform of the income distribution system, improve the primary distribution of national income, reform the redistribution of national income, improve the third distribution of national income, and do everything possible to alleviate the trend of widening income distribution gap among residents. Furthermore, this urgently needs to advance the real estate tax reform. This is because levying a real estate tax helps the problem of excessive concentration of resources in the real estate industry and helps solve the problem of the ever-widening gap between the rich and the poor in China. Since the monetization reform of the housing system was implemented in 1998, despite the outstanding achievements in the real estate market, the excessive development of the real estate industry has led to the widening gap between the rich and the poor in China. With the growth of the economy and the increase in household wealth, the form of retention of household wealth has gradually shifted from currency to real estate. However, in the real estate market development, high-income groups quickly realize wealth preservation and appreciation by purchasing real estate, while low-income groups have difficulty enjoying the huge dividends brought by the real estate market. As the real estate market prices continue to rise, the property income gap between residents who buy commercial houses and those who do not buy commercial houses is getting broader and wider. By levying real estate tax, it can give full play to the adjustment function of the real estate tax, straighten out the distribution structure of the real estate market, effectively suppress the phenomenon of overheated speculation in the real estate market, and gradually differentiate the real estate market, thereby effectively restraining the gap between the rich and the poor from being further widened. Based on the real estate bubble phenomenon and the positive role of the real estate tax in regulating national income, if China wants to achieve the goal of common prosperity, it is bound to levy the real estate tax.

Second, China's active promotion of real estate tax reform is an inherent need to promote the steady and healthy development of the real estate market. Since the monetization reform of the housing system was implemented in 1998, China's real estate market has developed rapidly, driving the development of construction, machinery and equipment manufacturing, finance and insurance, wood processing and furniture manufacturing, and other related industries, and promoting the rapid growth of the entire national economy. These all make the real estate industry a vital pillar industry of the national economy. Although China's real estate market has made brilliant achievements, it cannot be ignored that the rapid development of China's real estate market has also produced many problems: First, the supply and demand structure of the housing market is unreasonable, rigid demand cannot be met, and the supply of affordable housing is insufficient; Second, real estate resources have not been effectively used, and there are many vacant real estates, resulting in a waste of resources; Third, the strong demand for speculative investment has led to excessively rapid growth in housing prices in some central 
cities. Under this background, the central and local governments have adopted real estate regulation and control policies rounds. Regrettably, the overheating of the real estate market has not been effectively resolved, and real estate prices have even increased, which has brought significant challenges to the healthy development of the Chinese economy and financial stability. There are undoubtedly many reasons for these problems, but the lack of real estate taxes is crucial. Given this, to prevent the severe consequences that may be caused by the overheating of the real estate market, China urgently needs to change the past real estate regulation model. China needs to establish a long-term mechanism through the real estate tax system, give full play to the regulation function of the real estate tax, and help the real estate market enter a healthy and stable development track.

Finally, China's active promotion of real estate tax reform fundamentally solves the urgent land finance requirements. Since China implemented the tax-sharing system reform in 1994, although the central government has successfully resolved the fiscal dilemma, the revenue and expenditure of local governments have deteriorated sharply. In this context, more and more local governments are actively looking for new sources of income to improve their financial situation. As a limited and very precious non-renewable resource, land has a very high sale value. The government can easily harvest land rent, taxes, and non-tax income from land and related industries through a simple land sale process. Under these circumstances, coupled with the continuous acceleration of the process of urbanization, the rapid development of China's real estate market, and the continuous expansion of modern industries, land-related taxes, and fees and land transfer fees have become the most critical source of local fiscal revenues, responsible for local public expenditures, and supporting regional economic growth, thus forming the so-called land fiscal phenomenon. Although land finance has dramatically eased the financial pressure of local governments due to the tax-sharing system reform, the dependence of local governments on land finance has spawned various problems. For example, large-scale demolition and construction violate laws and regulations, force land occupation and land acquisition, resulting in land loss and reduction of arable land. Besides, to obtain more land revenue, local governments will not hesitate to raise land prices and maintain higher and higher housing prices in the name of real estate regulation. With the continuous rise of low prices and housing prices, the real estate industry has become one of the most popular and profitable sectors in the entire society and one of the industries most prone to corruption. Because they are accustomed to easily relying on the land for fiscal revenue, many local governments have become lazy, no longer paying attention to economic development, technological progress, and not focusing on improving the efficiency of the secondary and tertiary industries. Land finance has aggravated the overheating of the real estate market, suppressed the consumer demand of the people, created potential financial risks and financial risks, and cast a great shadow on the healthy and sustainable development of China's economy. With the gradual maturity of the real estate market and the continuous reduction of available land resources, the scale of land transfer fees will inevitably show a downward trend. In the future, the government may no longer obtain the fiscal revenue brought by high land transfer fees, which will make the land financial model challenging to continue. In this context, China urgently needs to promote the reform of real estate tax, seek stable and reliable new financial sources for local governments through the collection of the real estate tax, promote local governments to get rid of the dependence on land finance, and better optimize the allocation of resources.

\section{The feasibility of China's active pro- motion of real estate tax reform}

First of all, the mature experience of foreign real estate tax collection can provide valuable reference and enlightenment for China to actively implement real estate tax reform. Since the "Outline of the Twelfth Five-Year Plan for National Economic and Social Development" reviewed and approved by the Fourth Session of the Eleventh National People's Congress, it has proposed "Research and Promotion of Real Estate Tax Reform," although all sectors of society have heated discussions about whether China should promote the reform of real estate tax, the Chinese government has still not levied real estate tax until now. The reason why China's real estate tax reform is so slow is that the reform of the real estate tax affects the whole system and that China's real estate market is more complicated. Even many scholars believe that China does not have the conditions to collect real estate taxes. It is undeniable that China's real estate tax collection does have various problems, such as the object of real estate tax collection, tax rate setting, tax basis, exemption standard, real estate valuation, tax effect, collection procedure. However, we cannot completely deny the legitimacy of real estate taxes because there are certain technical difficulties in real estate taxation. More importantly, from a global perspective, the real estate tax has a relatively long history. Most countries and regions in the world have already levied real estate tax and successfully established a relatively complete real estate tax system, making real estate tax an essential source of local taxes and local government revenue. The practice has fully proved that the real estate tax system of various countries can help realize the real estate market regulation, curb real estate speculation, and stabilize the development of the real estate market. The successful experience of real estate tax systems in various countries in the world fully proves that although there are various technical problems in collecting real estate taxes, these technical problems are not unsolved. Although China's real estate market has a certain degree of particularity relative to foreign real estate markets, the Chinese and foreign real estate markets are essentially the product of a market economy and share many common laws. This deter- 
mines that China can solve various technical problems by drawing on successful foreign experiences or summarizing lessons during the real estate tax reform.

Secondly, the real estate tax pilot work in Shanghai and Chongqing has accumulated rich experience and valuable enlightenment for China to promote real estate tax reform further. Although China has not yet levied real estate tax nationwide, the municipal governments of Shanghai and Chongqing have implemented pilot reforms of individual housing real estate tax as early as 2011. Judging from the reform pilots in the past ten years, although Shanghai and Chongqing encountered various difficulties in real estate tax reform pilots, they did not even achieve the expected goals of all sectors of society. However, it is undeniable that the two places' real estate tax reform policy has also accumulated rich experience or useful enlightenment. For example, clarifying the nature and functional positioning of real estate tax plays an important role in the sound and healthy development of the real estate tax system and the real estate market. Whether a reasonable scope and tax rate of real estate tax can be set up will directly affect real estate regulation. Under the circumstances that the scope of the collection is too narrow, the scope of the exemption is too broad, the tax rate is too low, and the tax rate is inflexible. Real estate tax not only has a relatively limited impact on housing prices, but it is also challenging to bring considerable local fiscal revenue, as well as to adjust the gap between the rich and the poor reasonably and maintain social equity. Housing prices are affected by various factors, and real estate taxes cannot be used to achieve the goal of real estate regulation. The implementation of differentiated and progressive real estate tax rates can help control the growth and spread of the real estate bubble and reduce the infringement of the levy of real estate taxes on the basic housing needs of residents. Real estate tax collection requires a complete real estate appraisal technology system and professional real estate appraisal technical personnel. Real estate tax calculation should be based on the assessed price, not the transaction price. A complete real estate information registration system, information sharing system, tax base evaluation mechanism, and tax collection and management mechanism must be established to collect a real estate tax. The collection of real estate tax helps build a sound local tax system. Accumulate experience to improve the tax system; as an essential part of the financial system reform, the property tax reform should be planned and developed in a coordinated manner. A detailed summary of the experience and enlightenment of the real estate tax pilot work in Shanghai and Chongqing will help China set up a scientific and reasonable real estate tax system.

Finally, China's real estate market reforms and real estate regulation have laid a solid foundation for China to implement real estate tax reforms actively. Since China implemented the monetary reform of the housing system in 1998, with the gradual establishment and continuous improvement of the socialist market economic system, China's real estate reform has made brilliant achievements. For example, China has established a basic housing system compatible with the socialist market economic system, a real estate marketization mechanism has been formed, and a diversified housing security system has been established. The real estate reform has led to the rapid rise of the real estate industry, making the real estate industry a pillar industry for the development of the national economy. The real estate reform has turned the real estate industry into the engine of China's urbanization and has raised urbanization. The real estate reform has brought a large amount of fiscal revenue to local governments and laid an important financial foundation for local governments to provide good public services, carry out large-scale infrastructure construction, and improve people's livelihood. The real estate reform has changed people's consumption concepts and greatly improved the housing conditions of most families. Real estate has become an important family property for residents, and China has become one of the countries with the highest housing ownership rate. The real estate reform has made real estate the leading force for increasing residents' income, wealth, and consumption; the real estate reform has stimulated the development of many related industries and created many employment opportunities for the people. Although China's real estate reform has achieved great success, it has also produced a series of more severe problems, such as the bubble of real estate, the high dependence of local governments on land finance, excessively stimulated speculation in real estate, widening the gap between the rich and the poor, and breeding officials corruption. In order to maintain the healthy and stable development of the real estate market and prevent the economic crisis or financial crisis brought about by the real estate bubble, the central and local governments have launched rounds of real estate control. So far, although China's real estate tends to bubble, it is still in a tolerable range. The achievements of China's real estate market reform and real estate regulation can lay a good foundation for China's active implementation of real estate tax reform. For example, the various taxes and fees collected by the state in the process of commercial housing sales or second-hand housing sales provide a helpful reference and reference for collecting real estate taxes. Another example is the gradual implementation of the real estate registration system, the networking of real estate information, the strict household registration management system, and the real estate price appraisal system during the sale of second-hand housing, which has cleared many technical obstacles to the collection of real estate taxes.

\section{Conclusion}

Since the abolition of the welfare housing allocation policy and the implementation of the monetization reform of the housing system in 1998, China's real estate market has achieved rapid development, and even a relatively serious bubble phenomenon has occurred. Ensuring the healthy and stable development of the real estate market is related to 
China's political and economic destiny and related to the stability of the entire society and the well-being of citizens. Considering that the real estate tax reform affects the whole system. Since the Chinese Communist Party Central Committee first proposed the real estate tax reform in 2003, the Chinese government has been prolonged in the process of real estate tax reform, but also there have been various doubts about the real estate tax reform from all walks of life. Although the community's doubts about the real estate tax reform are desirable to a certain extent, the various views opposed to the real estate tax reform cannot fundamentally subvert the legitimacy of China's active promotion of the real estate tax reform. This is not only because China has a solid theoretical and realistic basis for actively promoting real estate tax reform but also has excellent urgency and strong feasibility. However, it is worth noting that although China has sufficient reasons to promote real estate tax reform actively, based on the complexity, importance, and arduousness of real estate tax reform, it is difficult for China to promote real estate tax reform overnight. For this reason, the Chinese government has adopted a relatively safe and gradual approach. That is, the Standing Committee of the National People's Congress first authorizes the State Council to formulate pilot measures for real estate tax reform and select representative cities to collect a real estate tax. After the expiration of the five-year pilot period, the State Council will summarize the pilot experience, and then the National People's Congress and its Standing Committee will formulate a law on the collection of real estate taxes and formally collect real estate taxes across the country.

\section{References}

[1] Liu J and Chen L. Research on the Legalization Construction of the Path of Real Estate Tax Reform. Law Science Magazine, 2014, 35(2): $1-12$. https://doi.org/10.16092/j.cnki.1001-618x.2014.02.012

[2] Liu J. Five-Dimensional Construction of the Legitimacy of Real Estate Tax Reform in China. Chinese Journal of Law, 2014, 36(2): 131-151.

[3] Jian S. A Study on Orientations and Ways of Real Estate Tax Reform in China. International Taxation in China, 2007, 7(2): 10-15. https://doi.org/10.19376/j.cnki.cn10-1142/f.2007.07.002

[4] Wei F. International Experience of Real Estate Tax Reform and the Situation of China. Reformation \& Strategy, 2016, 32(273): 146-149. https://doi.org/10.19376/j.cnki.cn10-1142/f.2007.07.002

[5] Li M and Zhu T. Real Estate Tax Reform in Transitional Economies. International Taxation in China, 2011, 5(3): 17-21. https://doi.org/10.19376/j.cnki.cn10-1142/f.2011.05.003 